\title{
In vitro digestibility and nutritional characterization of distillers dried grains with solubles according to the Cornell Net Carbohydrate and Protein System
}

\section{Digestibilidade in vitro e caracterização nutricional de grão seco de destilaria com solúveis segundo o sistema Cornell}

\author{
Luiz Juliano Valério Geron ${ }^{1 *}$; Jocilaine Garcia'; Kallynka Samara Martins Coelho²; \\ Sílvia Cristina de Aguiar ${ }^{1}$; Anderson de Moura Zanine ${ }^{3}$; \\ Alexandre Lima de Souza ${ }^{4}$; Joilma Toniolo Honório de Carvalho²; \\ Lucas Silva Roberto ${ }^{2}$; Eurico Lucas Sousa Neto ${ }^{1}$; Daniele de Jesus Ferreira ${ }^{3}$
}

\begin{abstract}
We evaluated the fractions of protein and carbohydrates in distillers dried grains with solubles (DDGS), corn grain (CG), soybean meal (SM), and corn silage (CS), as well as the in vitro digestibility (IVD) of DDGS, CG, SM, CS, rations containing 0.0, 8.0, 16.0, and 24.0\% DDGS, and in vitro fermentation parameters after $24 \mathrm{~h}$ of incubation. DDGS were obtained following microbial fermentation for ethanol production from a sugar and alcohol distillery located in the state of Mato Grosso - Brazil. The Cornell Net Carbohydrate and Protein System (CNCPS) was used to determine the protein and carbohydrate fractions of experimental diets. For the in vitro nutrient digestion assay using the experimental foods and experimental diets, two sheep with an average body weight of $26 \mathrm{~kg}$ were used as inoculum donors. The in vitro digestibility of food and feed was assayed in three replicates. Fraction A of DDGS CP was 88,71 , and $37 \%$ lower in relation to fraction A of SM, CG, and CS, respectively. Fraction B2 of DDGS protein contained $21 \% \mathrm{CP}$, which represents $78.84 \%$ of DDGS protein in fraction $\mathrm{B} 2$, and is higher than the $\mathrm{SM}$, which was $70.44 \%$. The $\mathrm{B} 3$ fraction of $\mathrm{CP}$, which is partly released during ruminal fermentation, was $18 \%$ lower for SM compared to DDGS, and is expressed in \%CP. For carbohydrate fractionation, the DDGS presented $8.64 \%$ for the A + B1 fraction on a DM basis, which was 62,86 , and $74 \%$ lower compared to those obtained for SM, CG. and CS, respectively. The hemicellulose and cellulose contents of DDGS were higher than those of SM, as verified in fraction B2, with a value of $46.92 \%$, expressed in DM. The in vitro digestibility coefficients (IVDC) of the DDGS nutrients did not differ $(p>0.05)$ in relation to those of the other experimental foods. The inclusion of DDGS in rations formulated for sheep did not change $(\mathrm{p}>0.05)$ the IVDC of DM, OM, CP. NDF, or ADF, with mean values of $70.93,70.64,59.58,52.83$, and $43.40 \%$, respectively. Therefore, DDGS comprise a proteinrich food containing more than $70 \% \mathrm{CP}$ in fraction $\mathrm{B} 2$, with a large amount of carbohydrates bound to the cell wall. In addition, DDGS possess a similar digestibility coefficient to corn grain and soybean meal; however, up to $24 \%$ can be included in feed formulations for ruminants without changing the in vitro digestibility coefficient of nutrients.
\end{abstract}

Key words: Rumen degradable protein. Ruminal fermentation. Sheep. Soybean meal.

\footnotetext{
${ }^{1}$ Profs., Universidade do Estado de Mato Grosso, UNEMAT, Pontes e Lacerda, MT, Brasil. E-mail: ljgeron@yahoo.com.br; jo@ unemat.br; scaguiar@unemat.br; euriconeto@unemat.br

2 Discentes, UNEMAT, Pontes e Lacerda, MT, Brasil. E-mail: coelho-ksm@hotmail.com; joilma thc@hotmail.com; zooteclucas@, hotmail.com

${ }^{3}$ Profs., Universidade Federal do Maranhão, UFMA, Chapadinha, MA, Brasil. Email: anderson.zanini@ibest.com.br; dany_ dosanjos@yahoo.com.br

${ }^{4}$ Prof., Universidade Federal de Mato Grosso, UFMT, Cuiabá, MT, Brasil. E-mail: alexandre@ufmt.br

* Author for correspondence
} 


\section{Resumo}

Foram avaliadas as frações da proteína e dos carboidratos de grãos secos de destilaria com solúveis (GSDS), grão de milho (GM), farelo de soja (FS), e silagem de milho (SM), e a digestibilidade in vitro (CDIV) do GSDS, GM, FS, SM e de rações contendo a inclusão de $0,0 \% ; 8,0 \% ; 16,0 \%$ e 24,0\% de GSDS, bem como os parâmetros de fermentação in vitro após 24 horas de incubação. O GSDS foi obtido após processo de fermentação microbiana para a produção do etanol, de uma destilaria de flex de açúcar e álcool localizada no estado de Mato Grosso - Brasil. Para determinação das frações proteicas e de carboidratos dos alimentos experimentais foi utilizado Cornell Net Carbohydrate and Protein System - CNCPS. Para o ensaio de digestão in vitro dos nutrientes dos alimentos experimentais e das rações experimentais foram utilizados dois ovinos com peso corporal médio de $26 \mathrm{~kg}$, como doadores de inóculo. O ensaio de digestibilidade in vitro dos alimentos e das rações foi conduzido com três repetições de campo. A fração A da PB do GSDS apresentou valores $88 \%, 71 \%$ e $37 \%$ menores em relação a fração A do FS, GM e SM, respectivamente. A fração B2 da proteína do GSDS apresentou um teor de $21 \%$ da $\mathrm{PB}$, o que representa $78,84 \%$ da proteína do GSDS na fração B2, valor superior ao do FS, que foi de $70,44 \%$. A fração B3 da PB, a qual parte escapa da fermentação ruminal foi $18 \%$ menor para o FS em relação ao GSDS, expresso em \% da PB. Para o fracionamento de carboidratos, o GSDS apresentou um valor para a fração A+ B1 de 8,64\% na MS resultado inferior em $62 \%$; 86\% e $74 \%$ aos obtidos para o FS, GM e SM. O GSDS apresentou teores de hemicelulose e celulose superior ao FS, como verificado na fração B2, com valor de 46,92 \% expresso na MS. Os coeficientes de digestibilidade in vitro (CDIV) dos nutrientes do GSDS não diferiu ( $p>0,05)$ em relação aos demais alimentos experimentais. A inclusão do GSDS em rações formuladas para ovinos não alterou ( $\mathrm{p}>0,05)$ o CDIV da MS; MO; PB; FDN e FDA, com valores médios de 70,93\%; 70,64\%; 59,58\%; 52,83\% e 43,40\%, respectivamente. Desta maneira, conclui-se que o grão seco de destilaria com solúveis apresenta-se como alimento proteico com mais de $70 \%$ da $\mathrm{PB}$ na fração $\mathrm{B} 2$ e possui levada quantidade de carboidratos ligados à parede celular. Além disso, o grão seco de destilaria com solúveis apresenta um coeficiente de digestibilidade semelhante ao do grão de milho e ao farelo de soja, contudo, este pode ser incluído em até $24 \%$ nas formulações de rações para ruminantes sem alterar o coeficiente de digestibilidade in vitro dos nutrientes.

Palavras-chave: Farelo de soja. Fermentação ruminal. Proteína degradável no rúmen. Ovinos.

\section{Introduction}

In recent years, several countries have intensified research into alternative energy sources that may replace petroleum, due to its high price and its detrimental effect on the environment. Therefore, agricultural production has diversified toward the production of ethanol and biodiesel. This has led to two major implications for animal production: first, consumers of ethanol and biodiesel compete directly with livestock production for energy sources (grains and oilseeds) and, second, the production of ethanol and biodiesel generates waste, which can be used in several processes, including animal feed. Examples of residues from ethanol production include sugarcane bagasse and distillers dried grains with solubles (DDGS), which contain around $31 \%$ crude protein - CP (PENZ JÚNIOR; GIANFELICE, 2008).
Evidence from the literature suggests that the production of $1.0 \mathrm{~L}$ of ethanol requires the fermentation of $2.5 \mathrm{~kg}$ of corn grain, and that the fermentation of this volume of grains can generate $0.3 \mathrm{~kg}$ of carbon dioxide and $0.8 \mathrm{~kg}$ of DDGS (LIM; YILDIRIM-AKSOY, 2008; BOTELHO, 2015). According to COASUL (2014), in 2014, the centralwestern region of Brazil processed 900 thousand tons of sugar cane and 185 thousand tons of corn grain for the generation of ethanol and sugar.

Following corn fermentation, DDGS is produced as a co-product of ethanol production, which allows the flex ethanol distilleries to remain sustainable during the production of ethanol from corn in relation to the use of sugarcane. The literature reports that DDGS can be used in animal feed, because it has protein characteristics, which can replace soybean meal, in order to reduce the cost 
of animal feed (SPIEHS et al., 2002; McKEOWN et al., 2009).

According to the Association of Soya and Maize Producers of Mato Grosso, (APROSOJA), the bromatological composition of DDGS produced in Brazil contains 96\% dry matter (DM), 36\% CP, $9 \%$ ether extract (EE), and 10\% crude fiber (CF) (APROSOJA, 2012). According to Valadares Filho et al. (2010), distillery grain has 32\% CP content, $30 \%$ acid detergent fiber (ADF), and 18\% aciddetergent insoluble nitrogen (ADIN).

According to Spiehs et al. (2002), DDGS produced in different ethanol distilleries in the South Dakota region of the United States showed 87 to $93 \%$ variation in DM, 28 to $32 \%$ variation in $\mathrm{CP}$, 8 to $12 \%$ variation of $\mathrm{EE}$, and 35 to $49 \%$ variation of NDF, as well as 3.661 to $3.838 \mathrm{Mcal} \mathrm{kg}^{-1}$ of metabolizable energy, and $70 \%$ of total digestible nutrients (TDN). According to these authors, the variation in the bromatological and, consequently, nutritional composition of DDGS can occur due to differences in the content of each nutrient that make up this co-product. This can result from the quality of the corn grain and the method of processing used in the ethanol distilleries. The three main factors that affect variability of the raw material (corn grain) of the DDGS are the bromatological and nutritional composition of the grain used by the distilleries, variation in the mixing ratio of cereal grains to ethanol production, and different drying times and temperatures for DDGS used by ethanol distilleries.

In view of the large-scale production, there is a need to generate technical and scientific information on the use of DDGS in ruminant feed in the state of Mato Grosso - Brazil, which will enable ethanol distilleries and cattle farmers to make better use of this co-product of the national ethanol industry.

To obtain technical knowledge of food to integrate a system of dietary calculations, the chemical and bromatological composition, and the proportion of food digested and used by the animal, should be evaluated (PEREIRA et al., 2010). Many methods have been developed over the years to carry out these analyses, with the objective of more accurately predicting the nutritional values of foods, so that they meet the energetic and protein demands generated by the productive and/or the reproductive functions of the animals (SOUZA et al., 2011). Among the different methods used to analyze food, special attention has been given to the Cornell Net Carbohydrate and Protein System (CNCPS), which was developed from mechanistic concepts, mainly regarding the nutrient dynamics in the gastrointestinal tract of ruminants (CARVALHO, 2012).

To evaluate the digestibility of food, in vitro techniques present advantages in their rapidity, physicochemical uniformity of the fermentation site, and convenience to maintain few fistulated animals (ALCALDE et al., 2001). In addition, they permit in vitro digestibility to be estimated for a large number of samples simultaneously with the use of an artificial incubator (SANTOS et al., 2000).

The objective of this study were to evaluate the protein and carbohydrate fractionation of DDGS, corn grain, soybean meal, and corn silage through CNCPS, and to evaluate the in vitro digestibility coefficient of nutrients and ruminal parameters of experimental foods and diets containing 0.0, 10.0, 20.0, and $30.0 \%$ DDGS.

\section{Material and Methods}

The study was conducted at the Pontes e Lacerda University Campus of the Universidade do Estado de Mato Grosso - UNEMAT, Brazil. DDGS was obtained from a sugar ethanol distillery.

To evaluate the in vitro digestibility (IVD) of the experimental foods (DDGS, CG, SM, and CS; Table 1) and experimental diets containing different levels of DDGS $(0.0,10.0,20.0$, and $30.0 \%$ based on DM; Table 2), two male, castrated, mixed-breed male sheep, with an average body weight of $26 \mathrm{~kg}$ and 10 months of age, were used as the inoculum 
donors (bacteria). The animals received a total mixed ration to meet their requirements following the recommendations of the NRC (2007) with a 65:35 forage-to-concentrate ratio.

Inoculum donor lambs were kept in indoor metabolism cages with free access to water and were fed twice daily (0800 and 1600) with basal feed containing $0.0 \%$ DDGS.

The IVD of the nutrients was determined in triplicate, using the one-stage technique described by Silva and Queiroz (2002) and adapted to a 24-h fermentation stage as described by Smith et al. (2010).

Table 1. Bromatological composition of experimental foods used in the formulation of experimental rations containing the inclusion of distillers dried grains with solubles (DDGS) evaluated in the determination of the in vitro digestibility coefficient (IVDC) of nutrients.

\begin{tabular}{lccccccccc}
\hline \multirow{2}{*}{ Foods } & \multicolumn{7}{c}{ Nutrients $(\%$ DM $)$} \\
\cline { 2 - 10 } & DM & OM & CP & EE & NDF & ADF & TC & NFC & TDN $^{1}$ \\
\hline CS & 29.33 & 93.36 & 7.54 & 3.59 & 54.38 & 28.58 & 82.23 & 27.85 & 61.30 \\
CG & 90.99 & 97.38 & 9.20 & 5.85 & 14.05 & 6.47 & 82.33 & 68.28 & 86.03 \\
SM & 91.29 & 92.69 & 49.26 & 2.19 & 15.37 & 10.97 & 41.24 & 25.87 & 80.73 \\
DDGS & 90.04 & 98.00 & 34.41 & 4.47 & 48.80 & 15.37 & 59.11 & 10.31 & 78.50 \\
\hline
\end{tabular}

CS: corn silage; CG: corn grain; SM: soybean meal; DDGS: distillers dried grain with solubles; DM: dry matter; OM: organic matter; CP: crude protein; EE: ethereal extract; NDF: neutral detergent fiber; ADF: acid detergent fiber; TC: total carbohydrate; NFC: non-fibrous carbohydrates and ${ }^{1} \mathrm{TDN}$ : total digestible nutrients - obtained from the literature (VALADARES FILHO et al., 2010 and SPHIES et al., 2002).

Table 2. Ingredients and bromatological composition of rations containing inclusion levels of distillers dried grains with solubles (DDGS).

\begin{tabular}{lcccc}
\hline \multirow{2}{*}{ Ingredients } & \multicolumn{3}{c}{ Levels of inclusion of the DDGS } \\
\cline { 2 - 4 } & $0.0 \%$ & $8.0 \%$ & $16.0 \%$ & $24.0 \%$ \\
\hline Corn silage (CS) & 65.0 & 65.0 & 65.0 & 65.0 \\
Corn grain (CG) & 21.5 & 18.0 & 14.5 & 11.0 \\
Soybean meal (SM) & 13.5 & 9.0 & 4.5 & 0.0 \\
Distillers dried grains with solubles (DDGS) & 0.0 & 8.0 & 16.0 & 24.0 \\
\hline \multicolumn{2}{c}{ Bromatological composition of rations (\% of DM) } \\
\hline dry matter (DM) & 50.95 & 50.86 & 50.77 & 50.69 \\
organic matter (OM) & 94.13 & 94.39 & 94.66 & 94.92 \\
crude protein (CP) & 13.53 & 13.74 & 13.96 & 14.17 \\
ethereal extract (EE) & 3.89 & 3.94 & 4.00 & 4.05 \\
neutral detergent fiber (NDF) & 40.44 & 43.16 & 45.88 & 48.61 \\
acid detergent fiber (ADF) & 21.45 & 21.96 & 22.47 & 22.98 \\
total carbohydrate (TC) & 76.72 & 76.71 & 76.70 & 76.69 \\
non-fibrous carbohydrates (NFC) & 36.27 & 33.55 & 30.82 & 28.09 \\
total digestible nutrients (TDN) & 69.24 & 68.88 & 68.51 & 68.15 \\
\hline
\end{tabular}

Sheep ruminal fluid was collected by vacuum suction pump in the morning, $2 \mathrm{~h}$ after the morning feed in order to obtain a suitable microbial population and a minimum number of food particles. The ruminal liquid was conditioned in a thermos flask at $39^{\circ} \mathrm{C}$.
After ruminal liquid was collected, the $\mathrm{pH}$ was measured and then mixed with artificial saliva, maintained under anaerobic conditions at a temperature of $39^{\circ} \mathrm{C}$ until it was added to the digestibility tubes containing samples of different foods and experimental rations. 
Three incubations were performed to reduce the effect of the collection day. Each sample $(0.5 \mathrm{~g})$ and $50 \mathrm{~mL}$ of the incubation solution $(37.5 \mathrm{~mL}$ artificial saliva and $12.5 \mathrm{~mL}$ ruminal liquid) were added to each tube, which were then purged with $\mathrm{CO}_{2}$. The tubes were then sealed with corks fitted with Bunsen valves and placed in a water bath with constant stirring at $39^{\circ} \mathrm{C}$. Every $2 \mathrm{~h}$, the tubes were gently shaken manually to aid the release of formed gases. Three tubes containing only incubation solution were incubated in each run to serve as controls, and three tubes containing only Tifton 85 hay (Cynodon) as index forage (SMITH et al., 2010).

After the 24-h incubation, fermentation was stopped by placing the tubes in a container containing crushed ice for $10 \mathrm{~min}$. The contents of the tubes were filtered on quantitative filter paper (black strip, 15-cm diameter for rapid filtration for thick and gelatinous precipitates), and the fermented content retained in the filters was placed in an oven at $105^{\circ} \mathrm{C}$ where they remained for $24 \mathrm{~h}$. After this period, the filters were weighed and the liquid that passed through the filter was stored for further analysis of ammoniacal nitrogen content $\left(\mathrm{N}-\mathrm{NH}_{3}\right)$.

The in vitro digestibility coefficient (IVDC) was determined by the following formula (SILVA; QUEIROZ, 2002):

\footnotetext{
sample weight ( $g$ of nutrient) - [weight of residue (g nutrient) - control weight ( $g$ of nutrient)] /sample weight (g of nutrient) $\times 100$
}

Immediately after the in vitro fermentation process $(24 \mathrm{~h})$, the $\mathrm{pH}$ of the fermented contents of the tubes was measured before filtration, using a digital $\mathrm{pH}$ meter. An aliquot $(20 \mathrm{~mL})$ of the fermented content after filtration was mixed with $0.2 \mathrm{~mL}$ of 1: 1 sulfuric acid to acidify the medium and stop fermentation. These samples were used to determine the concentration of ammoniacal nitrogen $\left(\mathrm{N}-\mathrm{NH}_{3}\right)$ of the fermented content after $24 \mathrm{~h}$ of in vitro incubation. The concentrations of $\mathrm{N}-\mathrm{NH}_{3}$ in the fermented samples were determined by distillation with potassium hydroxide $2 \mathrm{~mol} \mathrm{~L}^{-1} \mathrm{KOH}$, according to a technique described by Preston (1995).
Samples of food, feed, and food after in vitro digestion were processed in a Willey mill equipped with a 1-mm mesh sieve and stored in plastic pots previously labeled for further analysis.

The determination of dry matter (DM), organic matter (OM), crude protein (CP), and ethereal extract (EE) followed the recommendations of AOAC (2007). The neutral detergent fiber (NDF), acid detergent fiber (ADF), and permanganate lignin (PEL) contents of the food samples followed the recommendations of Van Soest et al. (1991). Neutral detergent insoluble nitrogen (NDIN), acid detergent insoluble nitrogen (ADIN), insoluble nitrogen in trichloroacetic acid (NI - TCA), and nitrogen insoluble in borate - phosphate buffer (NI - BPB) were estimated as described by Geron et al. (2007) and, subsequently, the fractions of proteins and carbohydrates were determined by the method described by Cornell (SNIFFEN et al., 1992).

Protein and carbohydrate fractionation of DDGS, SM, CG, and CS were analyzed according to CNCPS, and the following fractions were obtained: A, B1, B2, B3, and C. Fraction A was determined as described by Krishnamoorthy et al. (1983). The values of fractions B1, B2, and B3 were determined as described by Sniffen et al. (1992). Fraction $\mathrm{C}$ was determined by ADIN, according to the method described by Silva and Queiroz (2002), after obtaining the ADF, according to Van Soest et al. (1991).

The carbohydrate fractions of the experimental foods (DDGS, SM, CG, and CS) were obtained from the following equations, reported by Sniffen et al. (1992): total carbohydrates $($ TC) $=$ organic matter $(\mathrm{OM})-$ [ethereal extract $(\mathrm{EE})+(\mathrm{CP})]$. Fraction B2 was obtained by the equation: $\mathrm{B} 2=100 \times(\mathrm{NDF}$ $(\% \mathrm{DM})-\mathrm{NDIP}(\% \mathrm{CP}) \times 0.01 \times \mathrm{CP}(\% \mathrm{DM}))$ $\mathrm{NDF}(\% \mathrm{DM}) \times 0.01 \times$ lignin $\mathrm{NDF}) \times 2.4)) / \mathrm{TC}$ $(\% \mathrm{DM})$, where NDF is the neutral detergent fiber and NDIP is the neutral detergent insoluble protein. Carbohydrate fractions $\mathrm{A}$ and $\mathrm{C}$ were determined according to the formulas described by Sniffen et al. (1992). 
The statistical model used to evaluate the IVD of nutrients, the $\mathrm{pH}$ value, and ammoniacal nitrogen concentration of the four diets with different DDGS levels was a completely randomized experimental design. To evaluate the fractionation of carbohydrates and proteins of the individual foods, no statistical analyses were performed, since the foods presented different characteristics and classifications.

Statistical analyses of the variables studied for the nutrient IVD assay were interpreted in the Statistics and Genetic Analysis System (SAEG) through analysis of variance (UFV, 2007). For the differences obtained, Tukey's test was performed at $5 \%$ significance for foods and, for the diets containing DDGS, regression was performed at 5\% probability.

\section{Results and Discussion}

The IVDC of the DDGS nutrients did not differ compared to those of the other foods used in the formulations of experimental diets (Table 3). However, the DM IVDC of DDGS (63.34\%) was $14 \%$ lower than the SM (73.84\%), possibly due to the higher contents of the $\mathrm{B} 3$ and $\mathrm{C}$ fractions of $\mathrm{PB}$ and the $\mathrm{B} 2$ fraction of $\mathrm{TC}$, expressed in $\mathrm{DM}$, for DDGS in relation to SM. Similarly, the CP IVDC of the DDGS was $14 \%$ lower than the SM; it is possible that higher protein contents in fractions B2 and $\mathrm{C}$ contributed to these results.

Table 3. In vitro digestibility coefficient (IVDC) and in vitro fermentation parameters of distillers dried grain with soluble (DDGS) and other foods (corn silage - SM, corn grain - CG and soybean meal - SM) used in the formulation of experimental rations.

\begin{tabular}{|c|c|c|c|c|c|}
\hline \multirow{2}{*}{ Variables } & \multicolumn{4}{|c|}{ Experimental foods } & \multirow{2}{*}{$\begin{array}{l}\mathrm{CV} \\
(\%)\end{array}$} \\
\hline & $\mathrm{CS}$ & $\mathrm{CG}$ & SM & DDGS & \\
\hline \multicolumn{6}{|c|}{ In vitro digestibility coefficient (IVDC) } \\
\hline$I V \mathrm{DC} \mathrm{DM}$ & $64.78 \mathrm{a}$ & $74.78 \mathrm{a}$ & $73.84 \mathrm{a}$ & $63.34 \mathrm{a}$ & 13.96 \\
\hline$I V \mathrm{DC} \mathrm{OM}$ & $61.22 \mathrm{a}$ & $70.07 \mathrm{a}$ & $67.14 \mathrm{a}$ & $64.50 \mathrm{a}$ & 15.39 \\
\hline$I V \mathrm{DC} C \mathrm{P}$ & $74.51 \mathrm{a}$ & $79.01 \mathrm{a}$ & $82.10 \mathrm{a}$ & $70.66 \mathrm{a}$ & 13.05 \\
\hline$I V \mathrm{DC} \mathrm{NDF}$ & $60.37 \mathrm{a}$ & $61.17 \mathrm{a}$ & $41.50 \mathrm{a}$ & $52.60 \mathrm{a}$ & 21.27 \\
\hline$I V \mathrm{DC} \mathrm{ADF}$ & $51.96 \mathrm{a}$ & $42.73 \mathrm{a}$ & $37.13 \mathrm{a}$ & $46.12 \mathrm{a}$ & 35.29 \\
\hline \multicolumn{6}{|c|}{ In vitro fermentation parameters } \\
\hline $\mathrm{pH}$ of $\mathrm{FC}$ in vitro & $7.33 \mathrm{a}$ & $7.27 \mathrm{a}$ & $7.57 \mathrm{a}$ & $7.51 \mathrm{a}$ & 1.98 \\
\hline $\mathrm{N}-\mathrm{NH}_{3}$ of $\mathrm{FC}$ in vitro & $40.60 \mathrm{a}$ & $37.10 \mathrm{a}$ & $57.49 \mathrm{a}$ & $41.48 \mathrm{a}$ & 57.87 \\
\hline
\end{tabular}

DM: dry matter; OM: organic matter; CP: crude protein; EE: ethereal extract; NDF: neutral detergent fiber; ADF: acid detergent

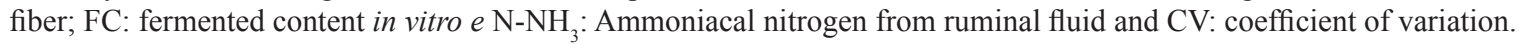

According to Thulasiraman et al. (2015), the chemical composition and in vitro digestibility of the DDGS obtained using the method described by Tilley and Terry (1963), demonstrated that the DM IVDC was $52.0 \%$, which is lower than that obtained in the present study (63.34\%). This difference may be associated with the bromatological composition of DDGS. According to these authors, DDGS presented CP of $47 \%$, crude fiber of $1.1 \%$, and EE of $1.2 \%$ of EE, which differ from the values observed in the present study (Table 1).
According to Kelzer et al. (2010), DDGS presented $92.0 \%$ total $\mathrm{CP}$ digestibility using the mobile bag technique as described by Kononoff et al. (2007). This value for the DC of CP was higher than the value of $70.6 \%$ observed in the present study (Table 3), and this variation may be associated with the methodology used, since the mobile bag method utilizes a cannulated animal, and study in vitro the environment is closed and controlled. In addition, variation in the bromatological composition of the DDGS used in the different studies may be 
consistent with the amplitude observed for the DC of PB. According to these authors, DDGS presented a DM content of $86.7 \%$, CP of $26.0 \%$, NDF of $30.2 \%$, and ADF of $13.0 \%$, which were lower than the values observed in the present study (Table 1).

The NDF and ADF IVDC of the DDGS were 21 and $19 \%$ respectively, which were higher than the SM. This may be due to the higher levels of the B2 and $\mathrm{C}$ fractions present in the TC for DDGS, when compared to the SM.

The $\mathrm{pH}$ and ammoniacal nitrogen $\left(\mathrm{N}-\mathrm{NH}_{3}\right)$ concentration of the fermented contents for the different foods evaluated following incubation in vitro for 24 hours did not differ, with mean values of 7.41 and $44.17 \mathrm{mg} \mathrm{N}^{-\mathrm{NH}_{3}}$ per $100 \mathrm{~mL}^{-1}$ of ruminal fluid, respectively.

Similarly, Pecka-Kiełb et al. (2015) evaluated the in vitro fermentation of DDGS and corn derivative, and demonstrated that DDGS did not alter methanogenesis or the ammonia concentration during in vitro fermentation for 8 and $24 \mathrm{~h}$, with an average value of $12.3 \mathrm{mg} \mathrm{N}-\mathrm{NH}_{3}$ per $100 \mathrm{~mL}^{-1}$ of the fermented content at 24 hours, and an average $\mathrm{pH}$ value of 6.65 for the content fermented with DDGS.

Geron et al. $(2014,2015)$ evaluated the DM IVD and fermentative parameters of diets with increasing levels of concentrate and different forages, and showed that the mean $\mathrm{pH}$ was 7.30 , regardless of the level of concentrate $(20,40,60$, and $80 \%)$ and forage evaluated. Normally, in in vivo studies on ruminal parameters, the ruminal liquid has a lower $\mathrm{pH}$ in relation to that observed in vitro; this may be due to the absorption dynamics of short-chain fatty acids and ammoniacal nitrogen in the rumen, which does not occur in in vitro studies.

The inclusion of $0.0,8.0,16.0$, and $24.0 \%$ of DDGS in rations formulated for sheep containing $13.5 \%$ of $\mathrm{CP}, 68.5 \%$ of TDN, and a forage-toconcentrate ratio of $65: 35$ did not change the IVDC of DM, OM, CP, NDF, and ADF, with mean values of $70.93,70.64,59.58,52.83$, and $43.40 \%$, respectively (Table 4 ).

Table 4. In vitro digestibility coefficient (IVDC) and in vitro fermentation parameters of rations for sheep containing levels of $0.0 \% ; 8.0 \% ; 16.0 \%$ and $24.0 \%$ inclusion of distillers dried grain with soluble (DDGS).

\begin{tabular}{|c|c|c|c|c|c|c|}
\hline \multirow{2}{*}{ Variables } & \multicolumn{4}{|c|}{ Rations with inclusion levels of DDGS } & \multirow{2}{*}{ Regres. } & \multirow{2}{*}{$\begin{array}{l}\mathrm{CV} \\
(\%)\end{array}$} \\
\hline & $0.0 \%$ & $8.0 \%$ & $16.0 \%$ & $24.0 \%$ & & \\
\hline \multicolumn{7}{|c|}{ In vitro digestibility coefficient (IVDC) } \\
\hline$I V \mathrm{DC} \mathrm{DM}$ & 71.64 & 68.97 & 71.16 & 71.91 & $\mathrm{Y}=70.93$ & 12.05 \\
\hline$I V \mathrm{DC} \mathrm{OM}$ & 70.83 & 68.89 & 71.89 & 70.94 & $Y=70.64$ & 14.47 \\
\hline$I V \mathrm{DC} C P$ & 63.78 & 58.40 & 57.41 & 58.73 & $Y=59.58$ & 36.08 \\
\hline$I V \mathrm{DC}$ NDF & 54.46 & 51.88 & 49.10 & 55.89 & $\mathrm{Y}=52.83$ & 14.57 \\
\hline$I V \mathrm{DC} \mathrm{ADF}$ & 41.05 & 45.27 & 40.02 & 47.25 & $\mathrm{Y}=43.40$ & 27.19 \\
\hline \multicolumn{7}{|c|}{ In vitro fermentation parameters } \\
\hline $\mathrm{pH}$ of $\mathrm{FC}$ in vitro & 7.39 & 7.34 & 7.50 & 7.43 & $\mathrm{Y}=7.41$ & 2.16 \\
\hline $\mathrm{N}-\mathrm{NH}_{3}$ of $\mathrm{FC}$ in vitro & 36.14 & 37.36 & 47.21 & 30.01 & $Y=37.68$ & 47.51 \\
\hline
\end{tabular}

DM: dry matter; OM: organic matter; CP: crude protein; EE: ethereal extract; NDF: neutral detergent fiber; ADF: acid detergent fiber; FC: fermented content in vitro e ${\mathrm{N}-\mathrm{NH}_{3}}_{3}$ : Ammoniacal nitrogen from ruminal fluid and CV: coefficient of variation. Regres.: regression equations.

The CP IVDC was 7.9\% lower for the diet with $24 \%$ DDGS (58.73\%) when compared to the diet with $0 \%$ DDGS $(63.78 \%)$. This variation may be associated with the rate of $\mathrm{CP}$ degradability of the DDGS, which was $47.04 \%$ of effective degradability at a passage rate of $0.05 \mathrm{~h}^{-1}$ according to Teixeira
(2014), while the SM shows effective degradability of $74.23 \%$ at $0.05 \mathrm{~h}^{-1}$ (TEIXEIRA, 2014). Thus, the lower availability of CP from the DDGS may have contributed to the variation in $\mathrm{CP} I V \mathrm{D}$ observed between the experimental diets. 
The CP fraction A of DDGS presented values that were 88,71 , and $37 \%$ lower than those of SM, CG, and CS, respectively (Table 5). The fermentation process for ethanol production occurs under conditions (temperature, time, hydrolysis process, etc.) that probably result in the solubilization of a large proportion of the $\mathrm{N}$. This hypothesis is corroborated by the difference between the $\mathrm{CP}$ fraction A of DDGS (0.39), CS (0.69\%), and CG (1.32\%). The content $34.41 \%$, the PB of the DDGS (Table 1) was 30\% lower than that of the SM with $49.26 \%$ of CP, which may have contributed to the $88 \%$ variation observed in the protein A fraction of these foods. Similarly, the B1 fraction of the DDGS protein was $66 \%$ lower in relation to the SM, but was close to that of the ground corn grain (CG).

Table 5. Nitrogen fractions and carbohydrates from foods experimental.

\begin{tabular}{|c|c|c|c|c|}
\hline \multirow[t]{2}{*}{ Variables } & \multicolumn{4}{|c|}{ Foods } \\
\hline & $\mathrm{CS}$ & CG & DDGS & SM \\
\hline \multicolumn{5}{|c|}{ Nitrogen fractions (\% DM) } \\
\hline $\mathrm{A}$ & 0.62 & 1.32 & 0.39 & 3.29 \\
\hline $\mathrm{B} 1$ & 2.50 & 1.39 & 1.70 & 5.04 \\
\hline $\mathrm{B} 2$ & 2.75 & 4.06 & 27.13 & 34.70 \\
\hline B3 & 1.00 & 1.88 & 3.49 & 4.32 \\
\hline $\mathrm{C}$ & 0.66 & 0.74 & 1.70 & 1.92 \\
\hline \multicolumn{5}{|c|}{ Nitrogen fractions $(\% \mathrm{CP})$} \\
\hline A & 8.28 & 12.27 & 1.12 & 6.68 \\
\hline $\mathrm{B} 1$ & 33.18 & 15.15 & 4.93 & 10.23 \\
\hline $\mathrm{B} 2$ & 36.51 & 44.12 & 78.84 & 70.44 \\
\hline B3 & 13.33 & 20.40 & 10.16 & 8.76 \\
\hline $\mathrm{C}$ & 8.69 & 8.06 & 4.95 & 3.89 \\
\hline \multicolumn{5}{|c|}{ Carbohydrates fractions (\% DM) } \\
\hline $\mathrm{A}+\mathrm{B} 1$ & 33.34 & 62.29 & 8.64 & 22.83 \\
\hline B2 & 43.63 & 19.72 & 46.92 & 17.99 \\
\hline $\mathrm{C}$ & 5.17 & 0.32 & 3.55 & 0.41 \\
\hline \multicolumn{5}{|c|}{ Carbohydrates fractions (\% TC) } \\
\hline $\mathrm{A}+\mathrm{B} 1$ & 40.66 & 75.66 & 14.62 & 55.36 \\
\hline $\mathrm{B} 2$ & 53.06 & 23.95 & 79.38 & 43.64 \\
\hline $\mathrm{C}$ & 6.29 & 0.39 & 6.00 & 1.01 \\
\hline
\end{tabular}

CS: corn silage; CG: corn grain; SM: soybean meal; DDGS: distillers dried grain with solubles. DM: dry matter; CP: crude protein; TC total carbohydrates.

DDGS DM presented $21 \%$ true protein (B2 fraction), which means that $78.84 \%$ of the DDGS protein is composed of true protein (fraction B2 expressed in \%CP). This is higher than that found for SM, which was $70.44 \%$ (Table 5) and is available for ruminal degradation. Corn silage (CS) and corn grain (CG), which correspond to forage and basal concentrate, respectively, presented a nitrogen content $44 \%$ lower in fraction B2 of the protein.

The CP of SM had a lower protein content $(18 \%)$, some of which escapes ruminal fermentation (fraction B3) in relation to DDGS, expressed in $\% \mathrm{CP}$. The variation in the $\mathrm{B} 3$ fraction of $\mathrm{CP}$ obtained between the DDGS and SM can be related to the fermentation process during the production of ethanol, which may have altered the characteristics of the nitrogenous fractions of the food, that is, transformed the B3 fraction into B2, through the action of bacteria and enzymes (JAKOBSEN et al., 2015; SILVA et al., 2016).

The CP of DDGS contained a $21 \%$ higher proportion of fraction $\mathrm{C}$ in relation to soybean meal; 
however, the fraction $\mathrm{C}$ content of DDGS was 43 and 39\% lower than CS and CG, respectively (Table $5)$.

Considering that the A + B1 fractions indicate a higher supply of non-protein nitrogen and degradable peptides in the rumen, the SM provided higher levels of these fractions $(16.91 \%$ of CP) than DDGS (6.05\% of CP). Conversely, the substitution of soybean meal by DDGS could reduce the ruminal degradation of the protein in the rations. This would increase the passage of dietary protein to the intestine, making it available for animal metabolism, since the B3 fraction was $21 \%$ higher for DDGS (10.16\% of CP) compared to SM $(8.76 \%$ of $\mathrm{CP}$ ).

However, in a study conducted by $\mathrm{Yu}$ et al. (2010), who evaluated the molecular structure of the DDGS protein, they used the protein fractionation of the DDGS, and presented a CP content of $10.5 \%$ for fraction $\mathrm{A}, 0.0 \% \mathrm{CP}$ for fraction $\mathrm{B} 1,55.0 \%$ $\mathrm{CP}$ for fraction $\mathrm{B} 2,30.7 \% \mathrm{CP}$ for fraction $\mathrm{B} 3$, and $3.9 \% \mathrm{CP}$ for fraction $\mathrm{C}$. The results of the present study differ from those reported previously in the literature (YU et al., 2010). This variation in the bromatological composition, and in the protein fractionation profile, may be associated with the grain varieties used by the ethanol distilleries, in addition to the fermentation methods used in Brazilian distilleries to produce ethanol from cereal grains (corn). According to Jakobsen et al. (2015), the use of different enzymatic complexes during ethanol production can alter the profile of the fibrous carbohydrates as well as the content of the passage protein. Silva et al. (2016) noted that the routes of ethanol production in the distilleries are divided into three processes depending on the raw material used, where the sugarcane passes through the extraction by pressure or diffusion, but the cereal grains are crushed and pass through enzymatic hydrolysis (JAKOBSEN et al., 2015). In addition, the use of sugarcane bagasse as a raw material for the production of ethanol is crushed and is subjected to acid hydrolysis. In this way, these processes alter the bromatological and nutritional characteristics of DDGS.

Kelzer et al. (2010) evaluated the protein fractionation of corn and its co-products (distillers wet grains with solubles, DDGS, and high protein distillery dry grain) and corroborated the data reported above. This indicates that the grain processing method used to obtain ethanol (JAKOBSEN et al., 2015), as well as the different enzymatic complexes used during the processing of the cereal grains, alter the profile of the protein fractions of the dry distillery grain. Those authors observed that the protein fractionation expressed in $\%$ CP for the different types of distillers wet grains with solubles varied from 7.4 to $18.6 \%$ for fraction A, 0.6 to $15.9 \%$ for fraction B1, 53.1 to $82.4 \%$ for fraction $\mathrm{B} 2,4.8$ to $11.0 \%$ for fraction $\mathrm{B} 3$, and 0.9 to $14.9 \%$ for fraction $\mathrm{C}$.

For the carbohydrate fractionation, the DDGS presented $8.64 \%$ in DM for the easily fermentable carbohydrates, sugars and starch (fraction A + B1; Table 3 ), which is $62 ; 86$, and $74 \%$ lower than the carbohydrates obtained for SM, CG, and CS, respectively. For the values of the fractionation of carbohydrates of easy fermentation (fraction A + B1) expressed in \% $\%$, the DDGS was $14.62 \%$, while the CG and the CS were 75.66 and $40.66 \%$, respectively. This may be due to the fermentation process, such that both CS and DDGS passed in relation to the corn grain. In addition, the CS contains easily fermented carbohydrates (starch) and fibrous carbohydrates (NDF and ADF; Table 1), which may have contributed to these results.

The potentially degradable B2 fraction of carbohydrates contained $79.38 \%$ of the TC for the DDGS, which was higher than that for CG and CS at 23.95 and $53.06 \%$, respectively. It is likely that the TC content of $59.11 \%$ (Table 1) for DDGS, compared to the CG and CS TC content of 82.33 and $82.23 \%$, respectively, may have corroborated this result. Another factor that may have contributed to the variation in the carbohydrate fraction $\mathrm{B} 2$ was 
the fermentation process applied to corn grain during ethanol production, in which the microorganisms and the enzymatic hydrolysis (JAKOBSEN et al., 2015) used most of the soluble carbohydrate fraction (fraction $\mathrm{A}+\mathrm{B} 1$ ), increasing the proportion of carbohydrates with lower solubility in fraction B2.

DDGS had higher hemicellulose and cellulose contents than SM, as verified in fraction B2, with a value of $46.92 \%$ expressed in DM. In the same way, DDGS presented a mean value of $79.38 \%$ TC for the B2 fraction in the form of cell walls, and only $43.64 \%$ SM expressed as \%TC. These results are also confirmed by the higher values of NDF ( $\%$ in DM) for DDGS, which were $48.80 \%$ in relation to 15.37\% SM (Table 1).

Fraction $\mathrm{C}$ of the carbohydrates (indigestible fiber) expressed in \%TC of the DDGS was 94 and $83 \%$ higher than the CG and SM, respectively, which may have been influenced by the fermentation process of the corn grain during ethanol production. This increased the concentration of structural and complex carbohydrates for DDGS. However, DDGS and $\mathrm{CS}$ showed similar values for the $\mathrm{C}$ fraction of the carbohydrates at 6.00 and $6.29 \%$ of the TC, respectively (Table 3 ). This may be associated with the TC profile of the CS, since this forage is made using the entire corn plant and probably contributed to the high content of fraction $\mathrm{C}$.

A study conducted by Lanzas et al. (2007) to evaluate carbohydrate fractionation, showed that DDGS produced in the United States presented $15.7 \% \mathrm{DM}$ for fraction $\mathrm{A}+\mathrm{B} 1,30.0 \% \mathrm{DM}$ for fraction $\mathrm{B} 2$, and $11.1 \% \mathrm{DM}$ for fraction $\mathrm{C}$. Variety in grains and in the processing methods used by distilleries, especially the use of different enzymatic complexes (JAKOBSEN et al., 2015), may have influenced the profile of the soluble and insoluble carbohydrates present in DDGS, resulting in variations for the different fractions of DDGS carbohydrates being obtained between studies.

\section{Conclusions}

DDGS present a lower in vitro digestibility coefficient than soybean meal; however, up to $24 \%$ can be included in feed formulations without changing the in vitro digestibility coefficient of the nutrients.

DDGS present protein food with more than $70 \%$ of the CP in fraction B2 (true protein), as well as presenting a high amount of carbohydrates bound to the cell wall.

In vivo studies of DDGS should be performed to confirm the results obtained in the in vitro studies, and to measure animal performance with the inclusion of this alternative source of protein in the ruminant diet.

\section{Acknowledgement}

To the Conselho Nacional de Desenvolvimento Cientifico e Tecnológico - CNPq, for financing this research.

\section{References}

ALCALDE, C. R.; MACHADO, R. M.; SANTOS, G. T.; PICOLLI, R.; JOBIM, C. C. Digestibilidade in vitro de alimentos com inóculos de líquido de rúmen ou de fezes de bovinos. Acta Scientiarum. Maringá v. 23, n. 4, p. 917-921, 2001.

ASSOCIAÇÃO DOS PRODUTORES DE SOJA E MILHO DE MATO GROSSO - APROSOJA Verticalização do milho marca circuito aprosoja em Campos de Júlio. 2012. Disponível em: <http:// tvcentrooeste.com/verticalizacao-de-milhomarcacircuito- aprosoja-em-campos-de-julio/>. Acesso em: 06 set. 2016.

ASSOCIATION OF OFFICIAL ANALYTICAL CHEMISTS - AOAC. Official methods of analysis of AOAC International. 18. ed. Maryland: AOAC, 2007. v. 2.

BOTELHO, R. M. Grãos secos de destilaria com solúveis em dietas para tilápia do Nilo. 2015. Tese (Doutorado em Zootecnia) - Universidade Estadual Paulista. Faculdade de Medicina Veterinária e Zootecnia, Botucatu. 
CARVALHO, E. M. Caracterização de alimentos para ruminantes segundo o Cornell net carbohydrate and protein system - CNCPS com adaptações. 2012. Tese (Doutorado em Zootecnia) - Universidade Federal de Viçosa, Viçosa, MG.

COOPERATIVA AGROPECUÁRIA SUDOESTE COASUL - LTDA. Milho rende etanol mais barato que o da cana. 2014. Disponível em: $<$ http://www.coasul.com. br/estabelece-o-procedimento-nos-casos-de-rescisoescontratuais-por-iniciativa-do-empregador-nas-rescisoescontratuais-como-iniciativa-da-empresa-devera-serverificada-primeiramente-a-situacao-de-cada/ $>$. Acesso em: 20 abr. 2016.

GERON, L. J. V.; RIBEIRO, M. G.; AGUIAR, S. C.; PIERANGELI, M. A. P.; SILVA, A. P.; SILVEIRA, R. Digestibilidade da matéria seca e parâmetros da fermentação in vitro de plantas forrageiras. Archives of Veterinary Science, Curitiba, v. 20, p. 38-49, 2015. Suplemento 1.

GERON, L. J. V.; TRAUTMANN-MACHADO, R. J.; GARCIA, J.; PACHECO. R.; RIBEIRO, M. G.; TAVARES, S. T.; SILVA; M. I.; CRISTO, R. L.; OLIVEIRA, E. B. Coeficiente de digestibilidade in vitro da matéria seca e parâmetros fermentativos de rações com níveis crescentes de concentrado. Revista de Ciências Agroambientais, Alta Floresta, v. 12, n. 1, p. 7-16, 2014.

GERON, L. J. V.; ZEOULA, L. M.; BRANCO, A. F.; ERKE, J. A.; PRADO, O. P. P.; JACOBI, G. Caracterização, fracionamento proteico, degradabilidade ruminal e digestibilidade in vitro da matéria seca e proteína bruta do resíduo de cervejaria úmido e fermentado. Acta Scientiarum. Animal Science, Maringá, v. 29, n. 3, p. 291-299, 2007.

JAKOBSEN, G. V.; JENSEN, B. B.; KNUDSEN, N. C. Improving the nutricional value of rapeseed cake and wheat dried distillers grains with solubles by addition of enzymes during liquid fermentation. Animal Feed Science and Technology. London, v. 208, n. 1, p. 198213, 2015.

KELZER, J. M.; KONONOFF, P. J.; TEDESCHI, L. O.; JENKINS, T. C.; KARGES, K.; GIBSON, M. L. Evaluation of protein fractionation and ruminal and intestinal digestibility of corn milling co-products. Journal of Dairy Science, Champaign, v. 93, n. 6, p. 2803-2815, 2010.

KONONOFF, P. J.; IVAN, S. K.; KLOPFENSTEIN, T. J. Estimation of the proportion of feed protein digested in the small intestine of cattle consuming wet corn gluten feed. Journal of Dairy Science, Champaign, v. 90, n. 3, p. 2377-2385, 2007.
KRISHNAMOORTHY, U.; SNIFFEN, C. J.; STERN, M. D.; VAN SOEST, P. J. Evaluation of a mathematical model of rumen digestion and in vitro simulation of rumen proteolysis to estimate the rumenundegraded nitrogen content of feedstuffs. British Journal of Nutrition, London, v. 50, n. 10, p. 555-568, 1983.

LANZAS, C.; SNIFFEN, C. J.; SEO, S.; TEDESCHI, L. O.; FOX, D. C. A revised CNCPS feed carbohydrate fractionation sheme for formulanting rations for ruminants. Animal Feed Science and Techonology, London, v. 136, n. 1, p. 167-190, 2007.

LIM, C.; YILDIRIM-AKSOY, M. Distillers dried grains with solubles as an alternative protein source in fish feeds. In: INTERNATIONAL SYMPOSIUM ON TILAPIA IN AQUACUlTURE, 8., Cairo, 2008. Proceedings... Cairo: University Egypt, p. 67-82, 2008.

McKEOWN, L. E.; CHAVES, A. V.; OBA, M.; DUGAN, M. E. R.; OKINE, E.; McALLISTER, T. A. Effects of corn, wheat or triticale dry distiller's grains with solubles on in vitro fermentation, growth performance and carcass traits of lambs. Canada Journal Animal Science. Lethbridge, v. 22, n. 1, p. 99-110, 2009.

NATIONAL RESEARCH COUNCIL - NRC. Nutrient requirements of small ruminants: sheep, goats, cervids, and new world camelids. Washington, D.C.: National Academy Press, 2007. 384 p.

PECKA-KIELB, E.; ZAWADZKI, W.; ZACHWIEJA, A.; MICHEL, O.; MAZUR, M.; MISTA, D. In vitro study of the effect of corn dried distillers grains with solubles on rumen fermentation in sheep. Polish Journal of Veterinary Sciences, Oczapowskiego, v. 18, n. 4, p. 751-758, 2015.

PENZ JÚNIOR, A. M.; GIANFELICE, M. O que fazer para substituir os insumos que podem migrar para a produção de bio-combustiveis. Acta Scientiae Veterinariae. Porto Alegre, v. 36, n. 1, p. 107-117, 2008.

PEREIRA, E. S.; PIMENTEL, P. G.; DUARTE, L. S.; MIZUBUTI, I. Y.; GHERMAN, G. L. A.; CARNEIRO, M. S. S.; REGADAS FILHO, J. G. L.; MAIA, A. S. G. Determinação das frações proteicas e de carboidratos e estimativas do valor energético de forrageiras e subprodutos da agroindústria produzidos no Nordeste Brasileiro. Semina: Ciências Agrárias, Londrina, v. 31, n. 4, p. 1079-1094, 2010.

PRESTON, T. R. Biological and chemical analytical methods. In: (Ed.). Tropical animal feeding: a manual for research workers. Rome: FAO, 1995. p. 191264. 
SANTOS, G. T.; ASSIS, M. A.; GONÇALVES, G. D.; MODESTO, E. C.; CECATO, U.; JOBIM, C. C.; DAMASCENO, J. C. Determinação da digestibilidade in vitro de gramíneas do gênero Cynodon com uso de diferentes metodologias. Acta Scientiarum.Animal Science, Maringá, v. 22, n. 3, p. 761-764, 2000.

SILVA, D. J.; QUEIROZ. A. C. Análise de alimentos: métodos químicos e biológicos. 2. ed. Viçosa: UFV, 2002. $178 \mathrm{p}$.

SILVA, J. R.; PERES NETTO, D.; SCUSSEL, V. M. Grãos secos de destilaria com solúveis, aplicação em alimentos e segurança: revisão. Publicação em Medicina Veterinária e Zootecnia - PEBVET, Londrina, v. 10, n. 3, p. 257-270, 2016.

SMITH, D. R.; DILORENZO, N.; LEIBOVICH, J.; MAY, M. L.; QUINN, M. J.; HOMM, J. W.; GALYEAN, M. L. Effects of sulfur and monensin concentrations on in vitro dry matter disappearance, hydrogen sulfide production, and volatile fatty acid concentrations in batch culture ruminal fermentations. Jornal of Animal Science, Champaign, v. 88, n. 2, p. 1503-1512, 2010.

SNIFFEN, C. J.; O'CONNOR, J. D.; VAN SOEST, P. $\mathrm{J}$. A net carbohydrate and protein system for evaluating cattle diets II. Carbohydrate and protein availability. Journal of Animal Science, Champaign, v. 70, n. 11, p. 3562-3577, 1992.

SOUZA, A. S.; ROCHA JÚNIOR, V. R.; MOTA, A. D. S.; PALMA, M. N. N.; FRANCO, M. O.; DUTRA, E. S.; SANTOS, C. C. R.; AGUIAS, A. C. R.; OLIVEIRA, C. R. ROCHA, W. J. B. Valor nutricional de frações da parte área de quatro variedades de mandioca. Revista Brasileira de Saúde e Produção Animal, Salvador, v. 12, n. 2, p. 441-445, 2011.

SPIEHS, M. J.; WHITNEY, M. H.; AND SHURSON, G. C. Nutrient database for distiller's dried grains with solubles produced from new ethanol plants in Minnesota and South Dakota. Journal of Animal Science, Champaign, v. 80, n. 4, p. 2639-2346, 2002.
TEIXEIRA, U. H. G. Modelos matemáticos para estimação dos parâmetros da cinética de degradação ruminal de coprodutos proteicos. 2014. Dissertação (Mestrado Zootecnia) - Universidade Federal de Mato Grosso. Instituto de Ciências Agrárias e Ambientais, Sinop - MT.

THULASIRAMAN, R.; KATHIRVELAN, C.; PURUSHOTHAMAN, M. R. Chemical composition and in vitro dry matter digestibility of dried distillers grain solubles. International Journal of Science, Environment and Technology, Namakkal, v. 4, n. 4, p. 1177-1180, 2015.

TILLEY, J. M. A.; TERRY, R. A. A two stage technique for the in vitro digestion of forage crops. Journal British Grassland Society. London, v. 18, n. 1, p. 104-111, 1963.

UNIVERSIDADE FEDERAL DE VIÇOSA - UFV. Sistemas de análises estatísticas e genéticas - SAEG. Versão 9.1. Viçosa: Imprensa Universitária, 2007. 150 p. (Manual do usuário).

VALADARES FILHO, S. C.; MACHADO, P. A. S.; CHIZZOTTI, M. L.; AMARAL, H. F.; MAGALHÃES, K. A.; ROCHA JÚNIOR, V. R.; CAPELLE, E. R. Tabelas brasileiras de composição de alimentos para bovinos. 3 . ed. Viçosa, MG: Universidade federal de Viçosa, UFV/ DZO, 2010. 502 p.

VAN SOEST, P. J.; ROBERTSON, J. B.; LEWIS, B. A. Methods for dietary fiber, neutral detergent fiber, and nonstarch polysaccharides in relation to animal nutrition. Journal of Dairy Science, Champaign, v. 74, n. 12, p. 3583-3597, 1991.

YU, P.; NUEZ-ORTÍN, W. G. Relationship of protein molecular structure to metabolisable proteins in different types of dried distillers grains with solubles: a novel approach. British Journal of Nutrition, London, v. 104, n. 3, p. 1429-1437, 2010. 